SAND9: 1007

UC-2020

Unlimited Release

Printed January 1995

\title{
POLLUTION PREVENTION OPPORTUNITY ASSESSMENT FOR THE SNL/CALIFORNIA \\ WASTE MANAGEMENT FACILITIES
}

\author{
Stacy Braye and Norman M. Phillips \\ Environmental Protection Department \\ Sandia National Laboratories/California
}

\begin{abstract}
This Pollution Prevention Opportunity Assessment was conducted to evaluate the Waste Management Facilities, Buildings 961 and 962-2. It documents the secondary waste streams generated from the processing of hazardous, radioactive, and mixed wastes. It also includes recommendations for possible ways to minimize waste.
\end{abstract}

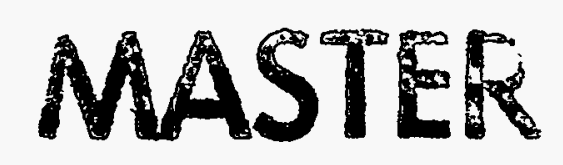




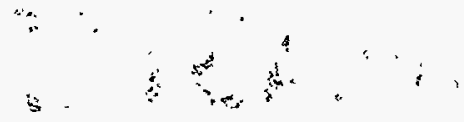




\section{DISCLAIMER}

This report was prepared as an account of work sponsored by an agency of the United States Government. Neither the United States Government nor any agency thereof, nor any of their employees, make any warranty, express or implied, or assumes any legal liability or responsibility for the accuracy, completeness, or usefulness of any information, apparatus, product, or process disclosed, or represents that its use would not infringe privately owned rights. Reference herein to any specific commercial product, process, or service by trade name, trademark, manufacturer, or otherwise does not necessarily constitute or imply its endorsement, recommendation, or favoring by the United States Government or any agency thereof. The views and opinions of authors expressed herein do not necessarily state or reflect those of the United States Government or any agency thereof. 


\section{DISCLAIMER}

Portions of this document may be illegible in electronic image products. Images are produced from the best available original document. 


\section{CONTENTS}

Page

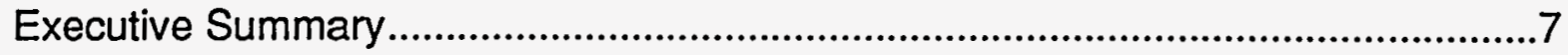

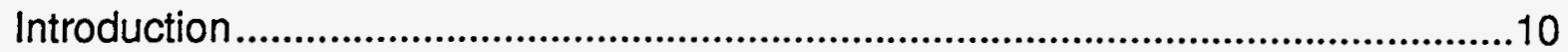

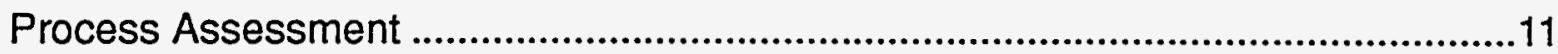

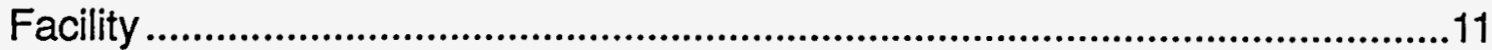

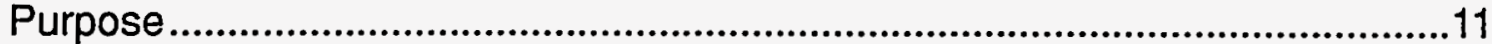

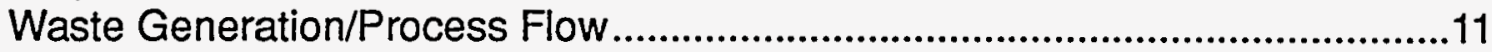

Options for Minimizing the Secondary Waste Streams ........................................18

Secondary Hazardous Waste Minimization Options ............................................18

Secondary Radioactive Waste Minimization Options...........................................25

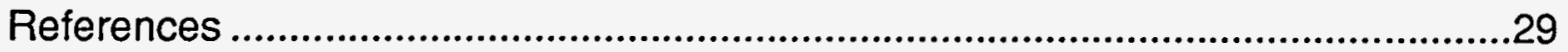

\section{ILLUSTRATIONS AND TABLES}

No.

Fig. 1 Layout of the waste management facilities-Bldgs. 961 and 962-2 ........12

Fig. 2 Process flow diagram for secondary hazardous waste .............................13

Fig. 3 Secondary hazardous waste-RCRA vs. non-RCRA-regulated................15

Fig. 4 Process flow diagram for secondary radioactive waste ...........................16

Fig. 5 Generators' empty containers attributed to the secondary waste stream

Fig. 6 Waste comparison showing secondary and total waste generated during spill cleanup.

Table 1 Contents of the Waste Management Facilities-Bldgs. 961 and 962-2 _..12

Table 2 Activities that Generate Secondary Hazardous Waste .............................14

Table 3 Secondary Hazardous Waste Generation Summary ................................15

Table 4 Activities that Generate Secondary Radioactive Waste .............................17

Table 5 Secondary Radioactive Waste Generation Summary ................................19

Table 6 Options to Reduce Secondary Hazardous Waste .......................................19

Table 7 Options to Reduce Secondary Radioactive Waste ...................................25 



\section{POLLUTION PREVENTION OPPORTUNITY ASSESSMENT WASTE MANAGEMENT FACILITIES}

\section{Executive Summary}

SNL/California's waste management facilities, Bldgs. 961 and 962-2, generate a secondary stream of hazardous and radioactive waste. This waste stream is generated mainly during the processing and handling of hazardous, radioactive, and mixed wastes (primary waste stream), which are generated by the laboratories, and when cleaning up spills. The secondary waste stream begins with the removal of a generator's hazardous, radioactive, and mixed waste from specified collection areas. The waste stream ends when the containers of processed waste are loaded for shipment off-site.

The total amount of secondary hazardous waste generated in the waste management facilities from January 1993 to July 1994 was $1160.6 \mathrm{~kg}$. The total amount of secondary radioactive waste generated during the same period was $1528.8 \mathrm{~kg}$ (with an activity of $0.070 \mathrm{mCi}$ ). Mixed waste usually is not generated in the secondary waste stream.

This pollution prevention opportunity assessment (PPOA) was conducted using the graded approach methodology developed by the Department of Energy (DOE) PPOA task group. The original method was modified to accommodate the needs of Sandia's site-specific processes. The options generated for potential hazardous waste minimization, cost savings, and environmental health and safety were the result of a wasie minimization team effort. The results of the team efforts are summarized below.

\section{Hazardous Waste Storage Facility, Building 962-2}

The options for this facility, as generated by the team, are summarized below. They are listed in order of importance, as ranked by the team.

\section{Recycle Glass Containers:}

Glass containers that contain designated hazardous waste can be rinsed clean and recycled through a glass recycling center. Approximately $90 \%$ of the glass currently sent out as hazardous waste can be recycled. The actual cost/saving of this option will be determined as the program is implemented.

2. Attribute the Disposal of Empty Containers to Generators' Waste Streams:

In the past, liquid waste was picked up from waste generators in various types of containers, and these containers were listed as part of Building 962-2's secondary waste stream. If the containers were attributed to the generators' waste streams and the cost of disposal was charged back to the generators, the generators would have an incentive to reduce the amount of liquid waste they generate, and therefore, the number of containers. 
3. Dispose of Empty Containers as Municipal Waste:

Any 5-gallon or smaller container that has not held acutely hazardous materials and that meets the California Code of Regulations (CCR) Title 22, \$66261.7 and the definitions of $\S 66260.10$ is considered empty and exempt from hazardous waste regulations. These containers can be drained, drip-dried, and disposed of as municipal waste. Therefore, the cost of disposing of the containers as hazardous waste would be saved.

The team considered the following options, but either they were not economically feasible or the waste reduction would be insignificant.

4. Train Laboratory Personnel to Prevent Spills:

High cost and minimal waste reduction.

5. Share Unused Chemicals Among Laboratories:

Because the secondary waste stream is small, benefits would not be significant.

6. Attribute Spill Cleanup to Generators' Waste Streams:

Benefits would not be significant.

7. Do Not Slop Liquid Chemicals:

Because the secondary waste stream is small, the reduction in cost and waste would not be significant.

8. Use Alternatives to Aerosols:

Because this secondary waste stream is small, benefits would not be significant.

9. Enclose Waste Facilities to Prevent Storm Water Runoff:

Cost would be excessive.

\section{Radioactive \& Mixed Waste Storage Facility, Building 961}

The options for this facility, as generated by the team, are summarized below. They are listed in order of importance, as ranked by the team.

1. Open Packages in a Lay-down Area instead of in Radiological Materials Management Areas (RMMAs):

Radiological materials are transferred to the waste management facility packaged in various containers. If a package is opened in an RMMA, the package and radiological material are both handled as radioactive waste. If a package were opened in a temporary lay-down area adjacent to the RMMA, the package would not be considered potentially contaminated and if after testing, it indeed were not contaminated, it could be disposed of as municipal waste. The cost of implementing this option would be minimal (about \$200), and most of this secondary waste stream would be eliminated. 
2. Package Tritium Cocktails in Plastic Bags for Disposal:

Currently, tritium scintillation cocktails are packaged in sectioned cardboard containers and are dumped into an open disposal drum in the waste management facility. Occasionally, the vials break, thereby increasing the quantity of airborne tritium and the risk of personnel exposure. If the cocktails were packaged in plastic bags before pickup, tritium would not become airborne if the vials were to break when placed in the drum. Implementation of this option would dramatically improve personnel and environmental safety.

3. Use 7-ml Vials for Tritium Scintillation Cocktails:

Smaller vials would be large enough to contain the amount of tritium scintillation cocktail waste generated and would reduce the amount of secondary waste generated.

4. Reduce the Number of RMMAs:

Reducing the number of RMMAs would greatly decrease the potential of cross contamination and would increase the control of radioactivity.

5. Improve Safety Habits:

Improving safety habits would save the disposal cost of cross-contaminated equipment and any occurrences caused by inattention to safety habits.

6. Install a Hand Blow Dryer:

Use of a hand blow dryer would eliminate contaminated paper hand towels from the waste stream; however, cost savings would be mininal.

7. Do not use Bldg. 961 as a Radioactive and Mixed Waste Facility:

The cost of storing and handling radioactive and mixed wastes would be reduced. 


\section{Introduction}

SNL/California has developed a waste minimization program in accordance with the requirements of DOE Orders 5400.1 and 5400.3.1,2 Its goals are to:

1. reduce the volume and toxicity of hazardous wastes generated on-site,

2. implement a system of tracking and reporting improvements,

3. design, review, and implement new projects, and

4. continuously improve existing projects.

Process-specific goals are directed toward new and existing processes and projects at SNL. PPOAs are the principal means by which these goals are established. The function of a PPOA is to identify viable pollution prevention options; to facilitate the implementation of the options and collect process statistics, such as material usage and waste generation; to establish the process baseline; and to document success in preventing pollution.

This PPOA was conducted on the waste management facilities to identify the secondary waste streams generated during the processing and handling of hazardous, radioactive, and mixed waste. It also recommends options for minimizing this waste stream.

The format for this PPOA is a Level III graded method (see the PPOA Plan for SNL/California), which was developed by the DOE PPOA task group. ${ }^{3}$ This method was modified to accommodate the needs of individual Sandia site processes.

For this PPOA, Sandia used mini-teams to coordinate the various, remotely related groups that would be required of a larger team. The mini-teams comprised site experts (see team lists below), who contributed to the part of the process related to their expertise. Mini-team meetings were held for each part of the process. All team members contributed to the overall process description, weighting evaluation, and option analysis and selection.

\section{Team A: Hazardous Waste Processing Team}
1. David Ross
3. Rodney Garcia
2. Richard Dagley
4. Edward Dolstra

Team B: Radioactive and Mixed Waste Processing Team
1. David Ross
4. Rodney Garcia
2. Tony Sorensen
5. Edward Dolstra
3. Albert Sandoval

Team C: Waste Minimization Team
1. Sally Raubfogel
7. Albert Sandoval
2. Alice Johnson-Duarte
8. Richard Dagley
3. Rodney Garcia
9. Gwyn Faulkner
4. Edward Dolstra
10. Tom Gorman (TRL Rep.)
5. David Ross
11. Sarah O'Connor
6. Tony Sorensen

Team D: Spill Cleanup Process and Spill Training Process Team

1. Rodney Garcia

2. Edward Dolstra 
The original weighted approach analysis is not part of this report; it is addressed in the PPOA Plan for SNL/California. ${ }^{3}$ All processes were ranked according to their importance. The weighted sums for the recommendations in this report uses a similar weighting method called the Ranking Matrix (1-5-10). This matrix shows the hierarchy of recommended options and the feasibility of each option.

\section{Process Assessment}

\section{Facility}

Waste Management Facilities, Bldgs. 961 and 962-2.

\section{Purpose}

Processing of hazardous, radioactive, and mixed waste.

\section{Waste Generation/Process Flow}

SNL/California's waste management facilities, Bldgs. 961 and 962-2 (see Fig. 1), generate a secondary waste stream of hazardous and radioactive waste. Table 1 lists the contents in each area of the waste management facilities. (The storage bays are part of Bldg. 962-2.) The secondary waste stream is generated mainly during the processing and handling of hazardous, radioactive, and mixed wastes, which are generated by the laboratories (primary waste), and when cleaning up spills. The processes generating these waste streams are discussed in two sections because hazardous waste is handled differently than radioactive and mixed waste.

\section{Secondary Hazardous Waste}

The generation of secondary hazardous waste begins when hazardous waste (including medical waste) is collected from the generators (see Fig. 2). Weekly collection is scheduled for each laboratory at SNL/California. Generators can also request pickup at other times. Each activity conducted in the processing of hazardous wastes and the personal protective equipment required are described in Table 2 . The secondary hazardous waste stream ends when the hazardous waste is shipped off site for disposal. 4

All secondary hazardous waste generated in the waste management facilities is regulated by the Hazardous Waste Control Law, the Resource Conservation Recovery Act (RCRA) or Medical Waste Management Act, which are state and federal laws, or as non-RCRA waste, which is regulated by California law. The percentage of waste generated in each of these categories is shown in Fig. 3.

Table 3 summarizes the amount of secondary hazardous waste generated by SNL/California between January 1993 and July 1994. ${ }^{5}$ 


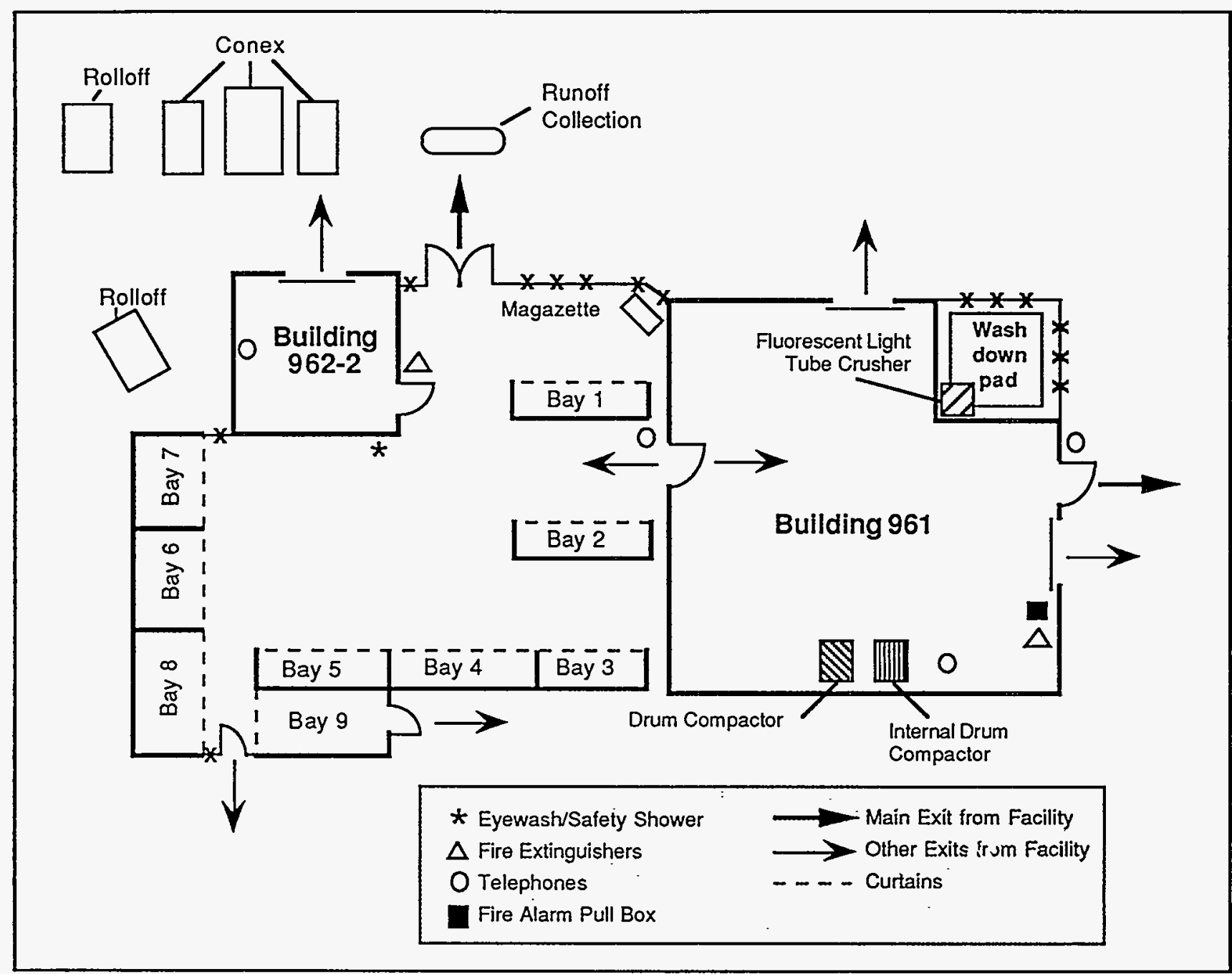

Figure 1. Layout of the waste management facilities-Buildings 961 and 962-2.

Table 1. Contents of the Waste Management Facilities_Bldgs. 961 and 962-2.

Area

Bldg. 961

Bldg. 962-2

Bay 1

Bay 2

Bay 3

Bay 4

Bay 5

Bay 6-8

Bay 9 and

Conexes

Magazette
Contents

Low-level radioactive waste and mixed waste storage facility

Segregation area: small quantities of miscellaneous chemicals, compactibles

Photochemicals, aerosols, class 9 wastes

Flammable liquids, solvents, class 6.1 PGIll wastes, class 9 wastes, non-RCRA wastes

Caustics

Compactible waste and batteries

Acids

Oil, coolant, fluorescent light tubes, contaminated dirt, sand with lead, PCBs, flammable compactibles, batteries, asbestos, class 9 wastes, non-RCRA wastes Spill control materials and packaging supplies

Combined oxidizing acids and solvents

Note: Lab packs are stored in storage bays and Bldg. 962-2 according to compatibility. 


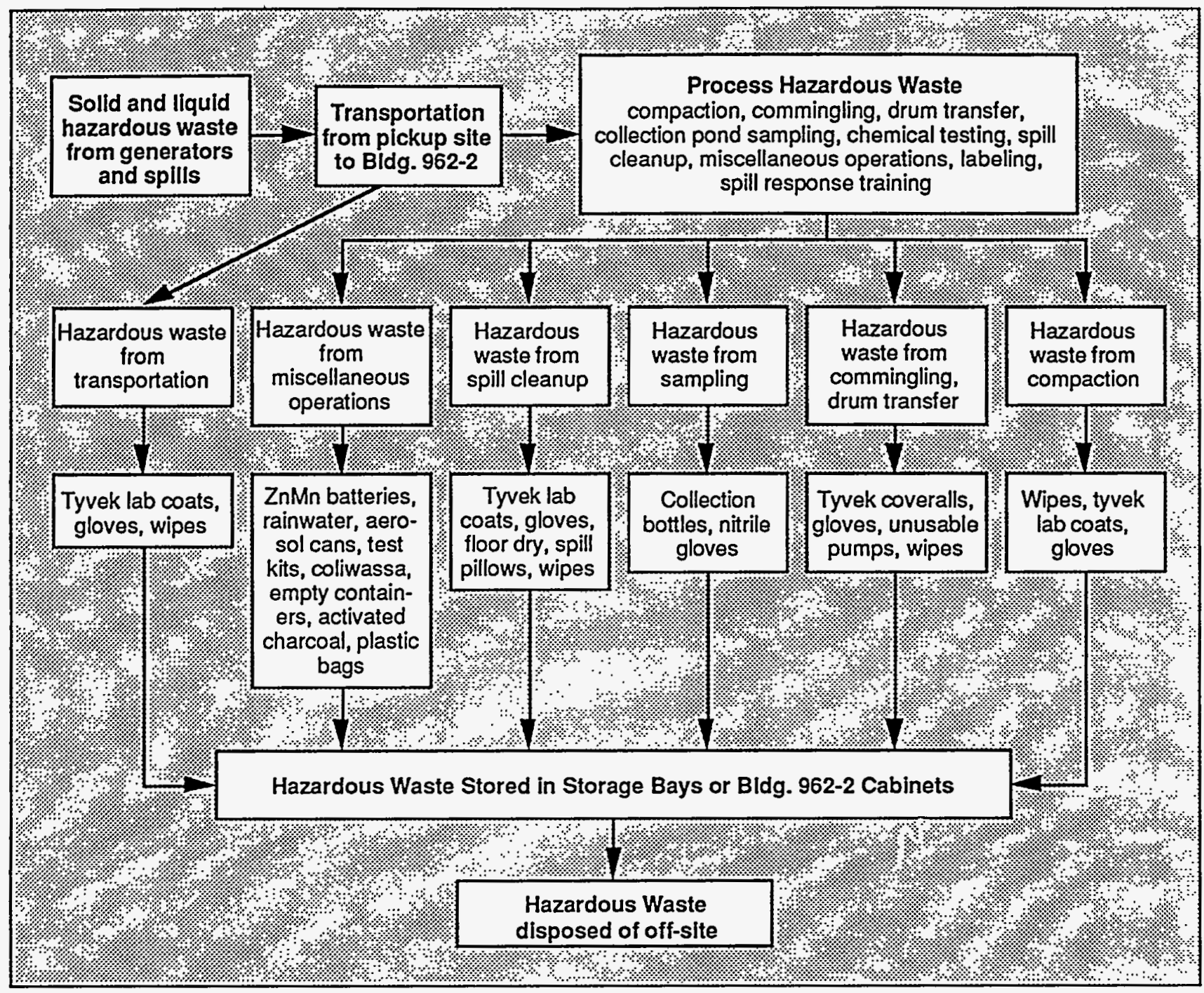

Figure 2. Process flow diagram for secondary hazardous waste. 
Table 2. Activities that Generate Secondary Hazardous Waste.

\begin{tabular}{|c|c|c|}
\hline Activity & $\begin{array}{l}\text { Type of Personal } \\
\text { Protective Equipment }\end{array}$ & Description \\
\hline $\begin{array}{l}\text { Pickup of hazardous } \\
\text { waste }\end{array}$ & $\begin{array}{l}\text { tyvek lab coat, steel-toed shoes, } \\
\text { safety glasses, poly gloves }\end{array}$ & $\begin{array}{l}\text { Waste management technicians ensure the } \\
\text { waste tag has been filled out correctly and } \\
\text { completely. Packages are inspected for } \\
\text { integrity. Commingled chemicals are tested for } \\
\mathrm{pH} \text { and oxidizing properties. }\end{array}$ \\
\hline $\begin{array}{l}\text { Commingling, } \\
\text { drum-to-drum or } \\
\text { carboy transfers, } \\
\text { and lab packing of } \\
\text { liquid chemicals }\end{array}$ & $\begin{array}{l}\text { full-body coveralls, booties, } \\
\text { hood, latex/nitrile gloves, } \\
\text { supplied breathing air mask }\end{array}$ & $\begin{array}{l}\text { The senior environmental technician approves } \\
\text { commingling of chemicals. Containers are } \\
\text { emptied into the appropriate drum through a } \\
\text { reusable funnel. Most of the coveralls are not } \\
\text { contaminated and are disposed of as municipal } \\
\text { waste. Empty containers are compacted. The } \\
\text { breathing air masks are cleaned and packaged } \\
\text { for reuse. }\end{array}$ \\
\hline $\begin{array}{l}\text { Compaction; } \\
\text { compactible items } \\
\text { include contaminated } \\
\text { personal protective } \\
\text { equipment, glass } \\
\text { containers, plastic, } \\
\text { paper, and small metal } \\
\text { containers. }\end{array}$ & $\begin{array}{l}\text { tyvek lab coat, gloves, safety } \\
\text { glasses }\end{array}$ & $\begin{array}{l}\text { Compactible waste is placed in a heavy-duty } \\
\text { plastic drum. No radiological work may be in } \\
\text { progress during compaction of hazardous } \\
\text { waste. At the end of the compaction process, } \\
\text { the ram is wiped down to remove any traces of } \\
\text { hazardous material, and the wipe is disposed } \\
\text { of as hazardous waste. }\end{array}$ \\
\hline $\begin{array}{l}\text { Handling of solid } \\
\text { waste, such as aero- } \\
\text { sol cans or batteries }\end{array}$ & $\begin{array}{l}\text { tyvek lab coat, steel-toed shoes, } \\
\text { safety glasses, poly gloves }\end{array}$ & $\begin{array}{l}\text { Batteries are stored in sealed plastic bags in a } \\
\text { cabinet. Aerosol cans ale disposed of whole in } \\
\text { a drum. }\end{array}$ \\
\hline $\begin{array}{l}\text { Testing and clean- } \\
\text { up of rainwater and } \\
\text { collected runoff } \\
\text { (pond water) }\end{array}$ & $\begin{array}{l}\text { tyvek lab coat, steel-toed shoes, } \\
\text { safety glasses, latex/nitrile gloves }\end{array}$ & $\begin{array}{l}\text { Rainwater from the collection pond in the } \\
\text { storage facility is sampled and tested quarterly. } \\
\text { Contaminated personal protective equipment, } \\
\text { as well as the testing paper and collection } \\
\text { bottles are disposed of as hazardous waste. }\end{array}$ \\
\hline $\begin{array}{l}\text { Spill cleanup and } \\
\text { solidification of } \\
\text { liquid residue }\end{array}$ & $\begin{array}{l}\text { depends on the type of spill- } \\
\text { can range from full-body coveralls } \\
\text { with supplied air masks to tyvek } \\
\text { lab coat, steel-toed shoes, plastic } \\
\text { booties, safety glasses, and poly } \\
\text { or latex/nitrile gloves }\end{array}$ & $\begin{array}{l}\text { Spill cleanup (including training conducted } \\
\text { every two months) generates the largest } \\
\text { quantity of waste in the secondary waste } \\
\text { stream. The materials used-floor dry, wipes, } \\
\text { spill pillows, and neutralizers, if applicable--are } \\
\text { disposed of as hazardous waste. }\end{array}$ \\
\hline Medical waste & $\begin{array}{l}\text { tyvek lab coat, steel-toed shoes, } \\
\text { leather gloves, poly gloves }\end{array}$ & $\begin{array}{l}\text { Packages are inspected carefully for integrity } \\
\text { before medical waste is picked up. }\end{array}$ \\
\hline Off-site shipment & $\begin{array}{l}\text { tyvek lab coat, steel-toed shoes, } \\
\text { poly gloves, safety glasses }\end{array}$ & $\begin{array}{l}\text { Personal protective equipment used in this } \\
\text { process is disposed of as hazardous waste. }\end{array}$ \\
\hline
\end{tabular}




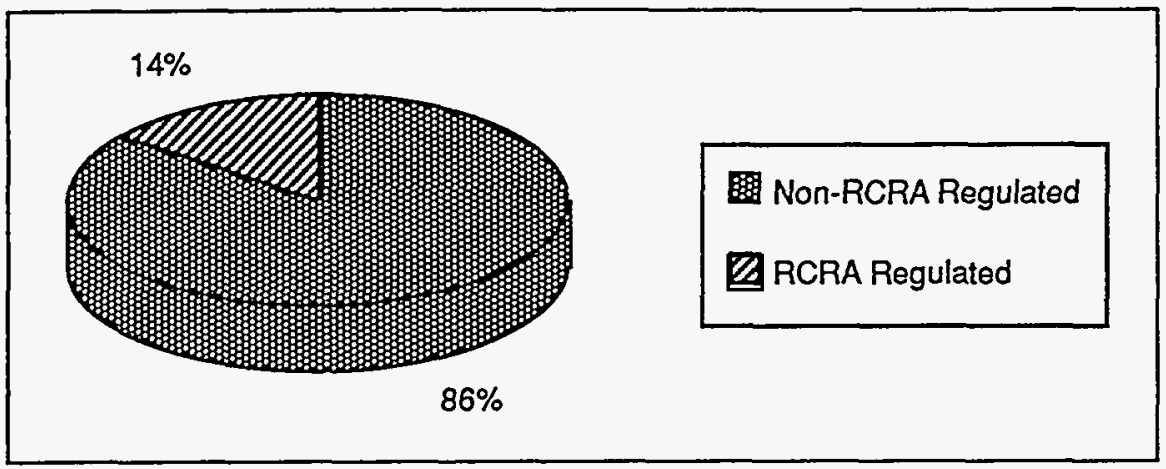

Figure 3. Secondary hazardous waste$R C R A$ os. non-RCRA-regulated.

Table 3. Secondary Hazardous Waste Generation Summary.

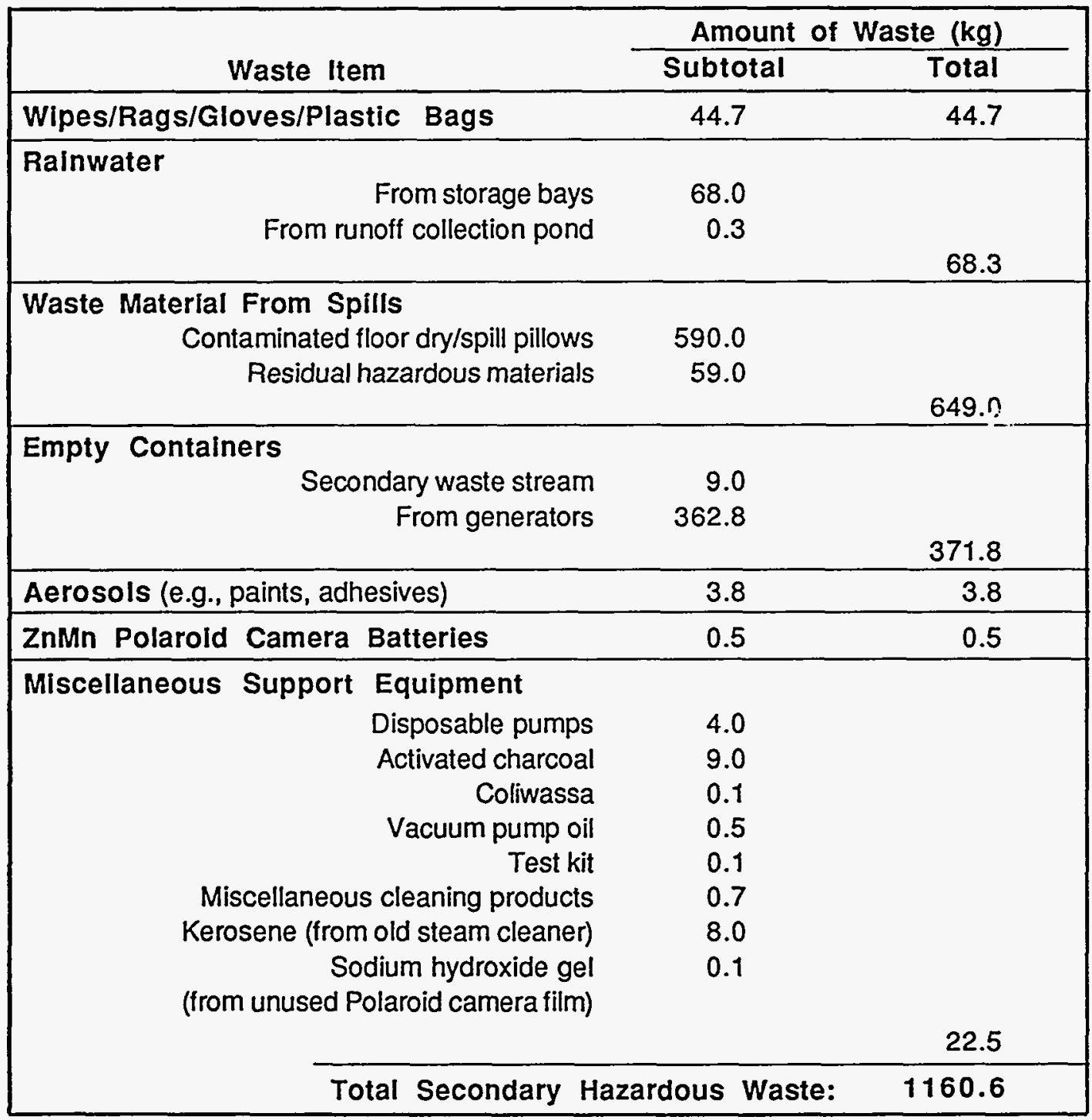




\section{Secondary Radioactive Waste}

The generation of secondary radioactive waste begins when radioactive or mixed waste is collected from the generators (see Fig. 4). Collection is scheduled as requested by the generator. The SNL/California health physicist must survey the waste and record the activity of each item before the waste is collected. Each activity conducted in the processing of radioactive and mixed wastes and the personal protective equipment required are described in Table 4 . The secondary radioactive waste stream ends when the containers are sent off site for disposal. 6

Studies performed on the tyvek and the paper products used in Bldg. 961 show that clothing tends to absorb airborne tritium. To ensure that radioactivity does not spread into the environment, waste management personnel treat all personal protective equipment as

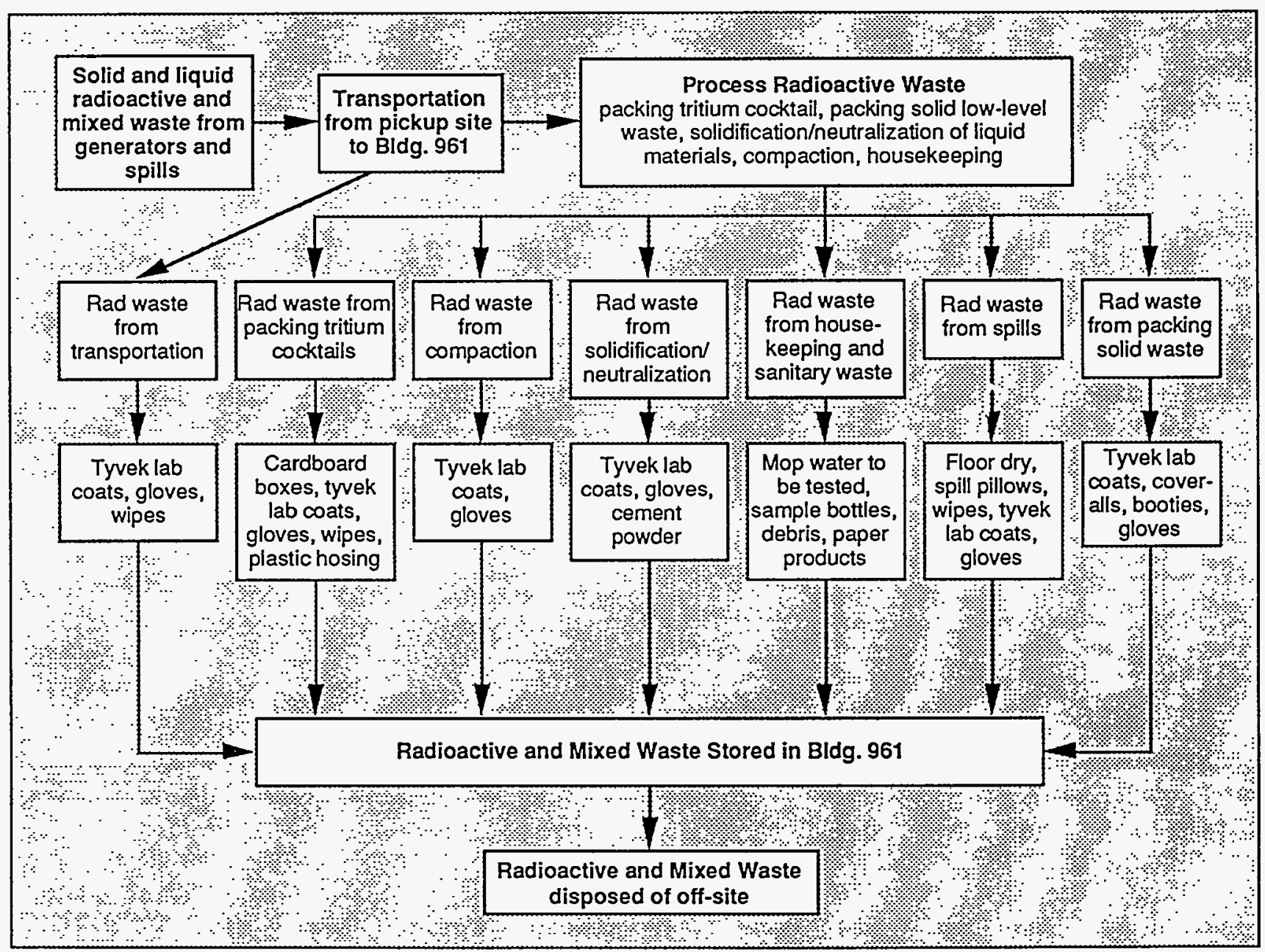

Figure 4. Process flow diagram for secondary radioactive waste. 
Table 4. Activities that Generate Secondary Radioactive Waste.

\begin{tabular}{|c|c|c|}
\hline Activity & $\begin{array}{l}\text { Type of Personal } \\
\text { Protective Equipment }\end{array}$ & Description \\
\hline $\begin{array}{l}\text { Plckup of radioactive } \\
\text { and mixed waste }\end{array}$ & $\begin{array}{l}\text { tyvek lab coat, steel-toed shoes, } \\
\text { safety glasses, poly gloves }\end{array}$ & $\begin{array}{l}\text { Radioactive waste representatives (RWRs) } \\
\text { ensure the tag has been filled out correctly and } \\
\text { completely. The radioactive waste packages } \\
\text { are approached cautiously and inspected for } \\
\text { integrity. Mixed waste is never transported with } \\
\text { radioactive or hazardous waste. }\end{array}$ \\
\hline $\begin{array}{l}\text { Processing of } \\
\text { tritium scintillation } \\
\text { cocktalls, which are } \\
\text { generated in the TRL. } \\
\text { A tritium scintillation } \\
\text { cocktail is a solution of } \\
\text { Uttima Gold AB (alkyl- } \\
\text { phenol, alkylnaphtha- } \\
\text { lene, bis-MSB PPO) } \\
\text { and tritium, which is } \\
\text { stored in glass } \\
\text { containers. }\end{array}$ & $\begin{array}{l}\text { tyvek lab coat, steel-toed shoes, } \\
\text { safety glasses, poly gloves }\end{array}$ & $\begin{array}{l}\text { Tritium scintillation cocktails are handled as a } \\
\text { mixed waste. The glass containers are placed } \\
\text { in cardboard trays for pickup and transported to } \\
\text { Bldg. } 961 \text {. Both personnel doors of the } \\
\text { building are left open during the deposition of } \\
\text { the cocktails into the tritium drum. The drum is } \\
\text { opened slightly so the air can be sampled to } \\
\text { ensure that the concentration of tritium at the } \\
\text { opening is at a safe level. If it is, the drum is } \\
\text { opened all the way. The cocktails are emptied } \\
\text { into the drum, and the drum is resealed. The } \\
\text { cardboard trays, tyvek lab coats, and gloves are } \\
\text { disposed of as compactible radioactive waste. }\end{array}$ \\
\hline $\begin{array}{l}\text { Noncompactible } \\
\text { solid radioactive } \\
\text { waste, such as out-of- } \\
\text { specification or } \\
\text { unusable equipment. }\end{array}$ & $\begin{array}{l}\text { tyvek lab coat, steel-toed shoes, } \\
\text { safety glasses, poly gloves } \\
\text { If climbing into the box is } \\
\text { required, the RWR must wear full- } \\
\text { body coveralls. }\end{array}$ & $\begin{array}{l}\text { Noncompactible solid radioactive waste is } \\
\text { stored and disposed of in DOT 7A boxes. } \\
\text { Polaroid pictures are taken of the } \\
\text { noncompactible waste and are stored in the } \\
\text { package files. The PJlaroid camera uses zinc- } \\
\text { manganese batteries, which are disposed of in } \\
\text { the secondary hazardous waste stream. }\end{array}$ \\
\hline $\begin{array}{l}\text { Compaction; } \\
\text { compactible items } \\
\text { include contaminated } \\
\text { personal protective } \\
\text { equipment, glass } \\
\text { containers, plastic, } \\
\text { paper and small metal } \\
\text { containers. }\end{array}$ & $\begin{array}{l}\text { tyvek lab coat, gloves, safety } \\
\text { glasses }\end{array}$ & $\begin{array}{l}\text { Compactible waste is placed in a heavy-duty } \\
\text { steel drum. At the end of the compaction } \\
\text { process, the ram is wiped down to remove any } \\
\text { traces of radioactive isotopes, and the wipe is } \\
\text { disposed of as radioactive waste. After the } \\
\text { equipment has been decontaminated, the } \\
\text { health physicist swipe-surveys it to ensure less } \\
\text { than } 1,000 \mathrm{DPM} / 100 \mathrm{~cm}^{2} \text { (a safe level). }\end{array}$ \\
\hline $\begin{array}{l}\text { Solidification and } \\
\text { neutralization }\end{array}$ & $\begin{array}{l}\text { fume hood, tyvek lab coat, steel- } \\
\text { toed shoes, safety glasses, poly } \\
\text { gloves. } \\
\text { Neutralization requires neoprene } \\
\text { or latex/nitrile gloves. }\end{array}$ & $\begin{array}{l}\text { Until recently, solid reusable equipment was } \\
\text { decontaminated with a steam cleaner. The } \\
\text { steam cleaner is no longer used, and the } \\
\text { chemicals used in it were neutralized and } \\
\text { solidified. }\end{array}$ \\
\hline
\end{tabular}


Table 4. Activities Generating Secondary Radioactive Waste (concluded).

\begin{tabular}{|l|l|l|}
\hline \multicolumn{1}{|c|}{ Activity } & \multicolumn{1}{|c|}{$\begin{array}{c}\text { Type of Personal } \\
\text { Protective Equipment }\end{array}$} & \multicolumn{1}{c|}{ Description } \\
\hline $\begin{array}{l}\text { Sampling of mop } \\
\text { water }\end{array}$ & $\begin{array}{l}\text { tyvek lab coat, steel-toed shoes, } \\
\text { safety glasses, chemical-resistant } \\
\text { gloves }\end{array}$ & $\begin{array}{l}\text { The Bldg. 961 floor is mopped weekly. The } \\
\text { mop water is stored in a collection tank and } \\
\text { analyzed routinely to determine its activity, if } \\
\text { any. Sampling containers are part of the } \\
\text { secondary radioactive waste stream. }\end{array}$ \\
\hline $\begin{array}{l}\text { Survey of reusable } \\
\text { equipment }\end{array}$ & $\begin{array}{l}\text { tyvek lab coat, gloves, safety } \\
\text { glasses }\end{array}$ & $\begin{array}{l}\text { Solid reusable equipment that becomes } \\
\text { contaminated can be released for unrestricted } \\
\text { handling if it can be surveyed on all accessible } \\
\text { surfaces with a reading of less than } \\
1,000 \text { DPM/100 cm². }\end{array}$ \\
\hline Off-site shipment & $\begin{array}{l}\text { tyvek lab coat, steel-toed shoes, } \\
\text { poly gloves, safety glasses }\end{array}$ & $\begin{array}{l}\text { Personal protective equipment used in this } \\
\text { process is disposed of as radioactive waste, if } \\
\text { contaminated. }\end{array}$ \\
\hline
\end{tabular}

radioactive waste if it has been worn when they have performed work involving a radioactive or mixed waste container (e.g., handling, packaging, solidifying or compacting waste, surveying, labeling). Tritium also can diffuse from any container in which it is placed. Therefore, tritium always has the potential of being airborne. However, the radioactive waste representatives (RWRs) sample airborne tritium in the waste drum before opening the drum all the way (see Table 4) to ensure safe levels. Therefore, the RWRs know the airborne tritium is in low enough concentrations that air breathing appara'tis is not necessary.

After performing any work that involves handling radioactive or mixed waste, other than tritium waste, the RWRs are required to survey their hands. After handling any of the radioactive or mixed waste, the RWRs are required to wash their hands. Hand washing generates low-level waste, which is disposed of as radioactive waste. Also, all tyvek lab coats and gloves are disposed of as radioactive waste.

Table 5 summarizes the amount of secondary radioactive waste generated by SNL/California between January 1993 and July 1994.7

\section{Options for Minimizing the Secondary Waste Streams}

\section{Secondary Hazardous Waste Minimization Options} (Process Index \#AL-SNL/CA-962-2, BIdg. 962-2)

The following options are listed in order of importance, as ranked in the 1-5-10 Matrix and the feasibility scoring. Feasibility of implementation is discussed with each option. Table 6 summarizes the options, including their respective normalized score and rank. 
Table 5. Secondary Radioactive Waste Generation Summary.

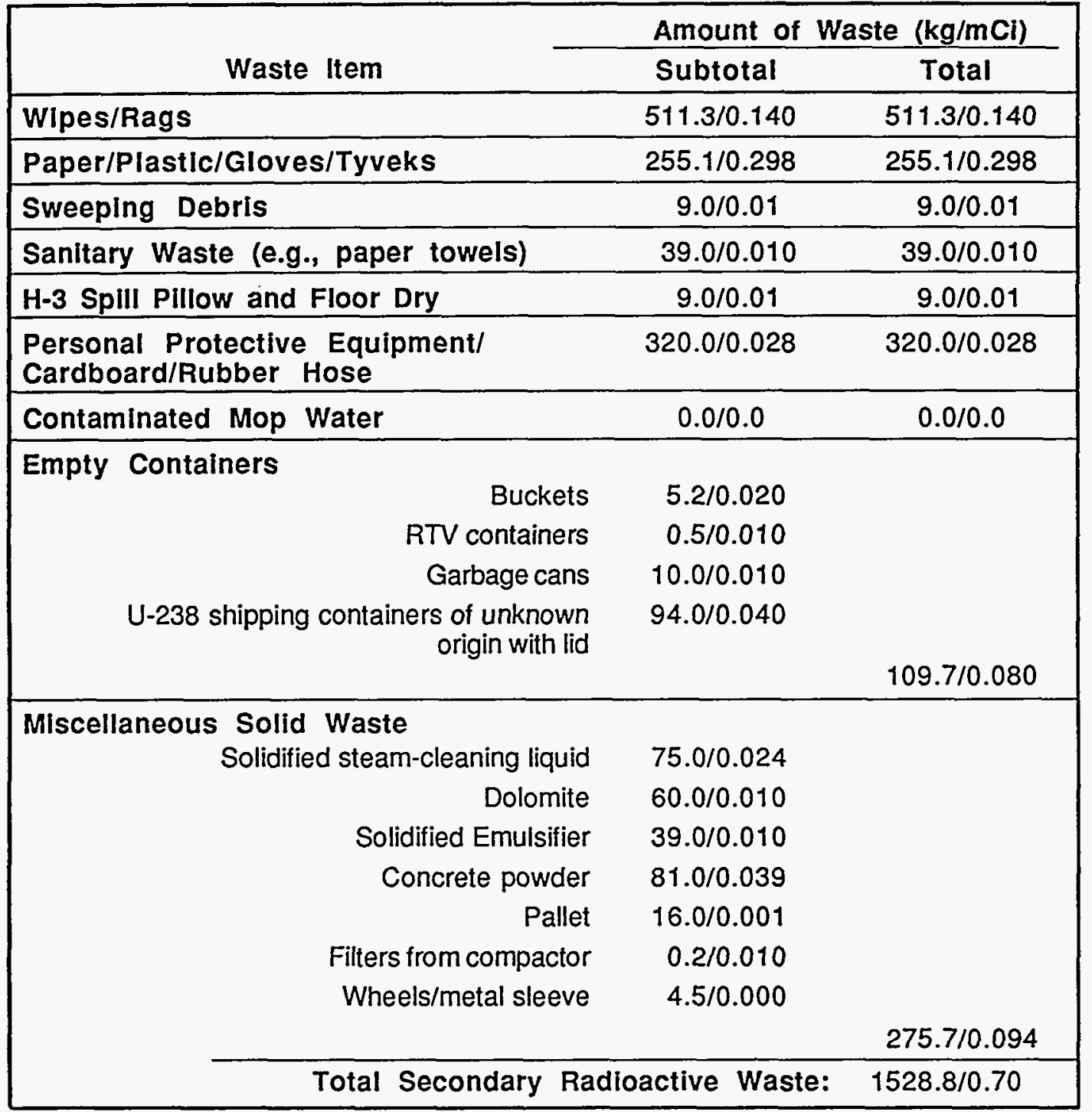

Table 6. Options to Reduce Secondary Hazardous Waste.

\begin{tabular}{|c|l|c|}
\hline Rank & \multicolumn{1}{|c|}{ Option } & Total Points \\
\hline 1 & Glass recycling & 954 \\
\hline 2 & Attribute the disposal of empty containers to generators' waste streams & 930 \\
\hline 3 & Dispose of empty containers as municipal waste & 879 \\
\hline 4 & Train lab personnel to prevent spills & 829 \\
\hline 5 & Share unused chemicals among laboratories & 828 \\
\hline 6 & Attribute spill cleanup to generator's (spiller's) waste stream & 813 \\
\hline 7 & Do not slop liquid chemicals & 754 \\
\hline 8 & Use alternatives to aerosol cans & 740 \\
\hline 9 & Enclose waste management facilities to prevent storm water runoff & 709 \\
\hline
\end{tabular}




\section{Option \#1 Glass Recycling}

Description: Sandia recently began recycling empty glass containers to minimize glass disposed of as hazardous waste. ${ }^{8}$ This recycling activity includes glass containers generated in the secondary hazardous waste stream. The glass containers are rinsed and dried for a designated period of time, depending on the type of hazardous material they contained. The rinsate is handled as a hazardous waste.

Type: Recycling

Feasibility: This option is being implemented site-wide with little or no impact on waste generators or other organizations. Rinsing and handling the glass containers is more timeconsuming than crushing them, and space for this process had to be made available.

Estimated cost: The cost to recycle glass containers is $\$ 25$ per month to rent the bin for storing recyclable glass, plus $\$ 15$ for the recycler to transfer the bin to the recycling site. Two drying racks, which cost $\$ 360$, were also required.

Estimated savings: The amount of glass containers disposed of site-wide is about $50 \mathrm{~kg}$ per month. ${ }^{5}$ The cost of disposing of a $200-\mathrm{kg}$ drum is $\$ 250$; therefore, the total cost of disposal is about $\$ 800.00$ per year. The savings would be offset slightly by the cost of rinsate disposal. The actual costs/savings will be studied as the program is implemented.

Anticipated Reduction in Quantity: The total amount of glass disposed of per year is approximately $600 \mathrm{~kg}$. Waste reduction is anticipated to be about $90 \%$ of the glass containers disposed of each year. (Note: In 1993, all glass containers were attributed to the secondary waste stream. Now, only glass containers used in the waste management facilities are attributed to the secondary waste stream. All others are attributed to generators' waste streams. See Option \#2.)

\section{Option \#2 Attribute the Disposal of Empty Containers to Generators' Waste Stream}

Description: Liquid waste usually is picked up in glass or plastic containers. After the hazardous liquid has been commingled into the appropriate drum, the empty containers are compacted. Generators' empty containers are listed on the container log as part of the secondary waste stream. In January 1994, the waste management technicians were instructed to indicate on the hazardous waste identification tag which containers are generators' empty containers. An additional charge back program could be initiated.

Type: Operations/Procedural Change

Feasibility: Empty containers are now attributed to the generators' ${ }^{\prime}$ waste streams. Figure 5 shows the amount of container waste that was inappropriately attributed to the secondary waste stream in 1993.

\section{Estimated Cost: None.}

Estimated Savings: The amount of generators' empty containers is about $30 \mathrm{~kg}$ per month. Disposal of a $200-\mathrm{kg}$ drum costs $\$ 250$. The total cost of disposal is approximately $\$ 400.00$ per year. Sandia will still pay for disposal, but generators will have a monetary incentive to decrease the amount of empty container waste they generate.

Anticipated Reduction in Quantity: The amount of empty containers considered part of the secondary waste stream will decrease significantly. 


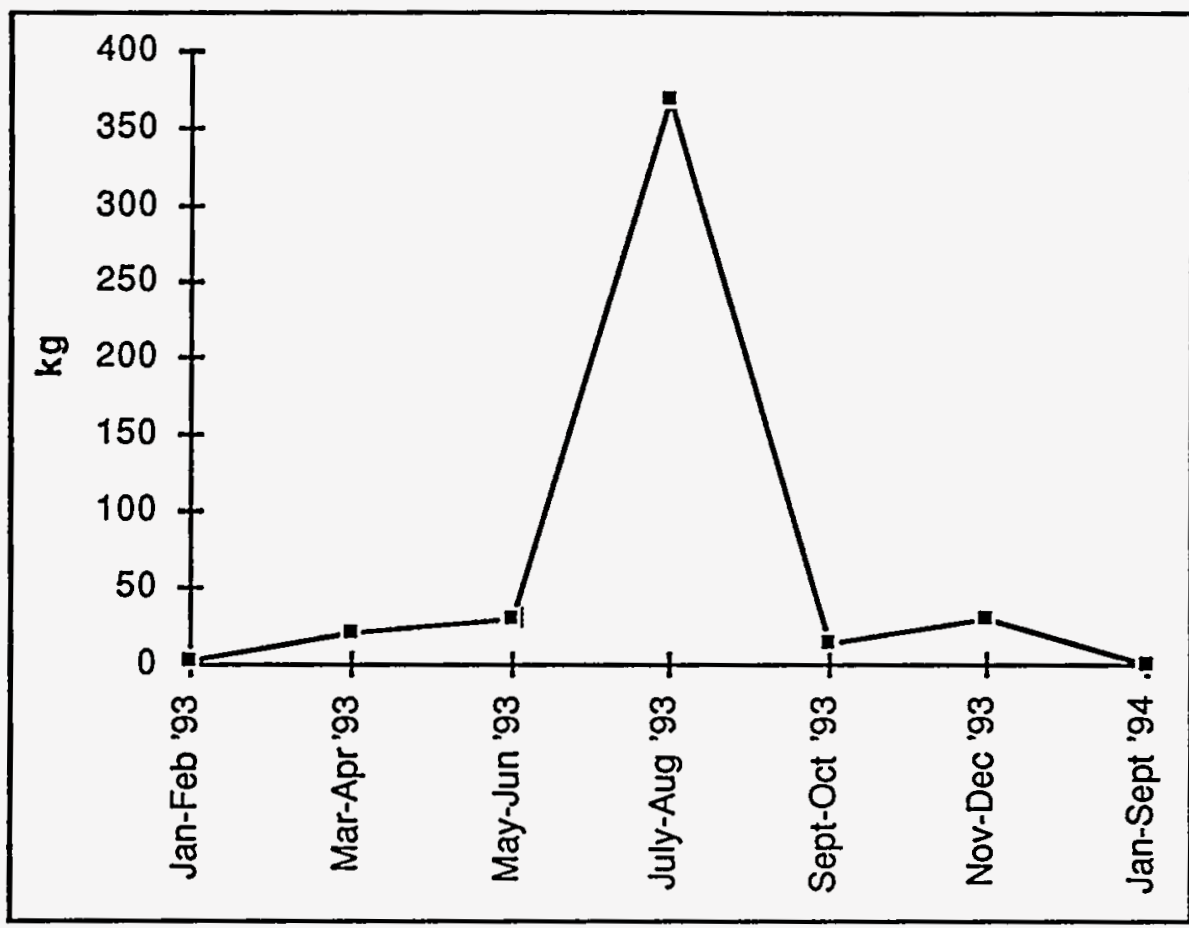

Figure 5. Generators' empty containers attributed to the secondary waste stream.

\section{Option \#3 Dispose of Empty Containers as Municipal Waste}

Description: A five-gallon or smaller container that has not held acutely hazardous material, including but not limited to waste, and meets the requirements of California Code of Regulations (CCR), Title 22, \$66261.7, and the definitions of $\$ 66260.13$ is considered empty (some solvents are acceptable, but no waste containing oil). Therefore, it is exempt from hazardous waste regulations.

Type: Operation/Procedural Changes

Feasibility: Containers that fit the above category may be drained sufficiently over the drum during commingling and allowed to drip-dry over the funnel for a short time. This procedure would eliminate the need for drip trays or other drainage devices, which require cleaning. To ensure the regulations' conditions are met, unannounced audits could be conducted periodically.

Estimated Cost: Only the additional time (short) to completely drain the containers.

Estimated Savings: The cost of recycling or disposing of the containers as compacted hazardous waste would be saved. The acutely hazardous glass bottles could be handled per Option \#1 (rinsed for recycling). Glass bottles that did not hold acutely hazardous materials would not need to be rinsed to be disposed of as municipal waste.

Anticipated Reduction in Quantity: The quantity of containers handled is approximately $372 \mathrm{~kg}$ per year. If two-thirds of these containers could be drained completely, $250 \mathrm{~kg}$ of waste per year would not need hazard handling and disposal. If this option were implemented, the amount of rinsate produced in Option \#1 (which is disposed of as hazardous waste) would be greatly reduced. 


\section{Option \#4 Train Laboratory Personnel to Prevent Spills}

Description: This option is closely linked to Option \#6. Spills are the leading source of secondary hazardous waste. The amounts of total and secondary waste generated as a result of spills from January 1993 to July 1994 are shown in Fig. 6. The current spill response training teaches Sandia employees how to handle spills. If training also were to focus on spill prevention, the waste stream might shrink, and safety of laboratory personnel would be enhanced.

Type: Education

Feasibility: Training can be given to personnel in each laboratory. This way, the laboratory setup and specific chemicals and hazardous materials used can be addressed. This process would minimize the amount of personnel time spent in "down time." The training would present handling techniques, propose changes to improve the safety of the facility, and propose possible changes in the hazardous materials handling areas.

Estimated Cost/Savings: Start-up expenses for the employee training would be the cost of developing a training package. The cost for conducting the training would be the time of the laboratory personnel involved and the instructor's time. The estimated cost of a one- to two- hour training session for up to 20 people would be about $\$ 500$ per hour. However, the anticipated savings would not make up for the cost. Therefore, this option is not economically feasible.

Anticipated Reduction in Quantity: The number of spills probably would not decrease significantly.

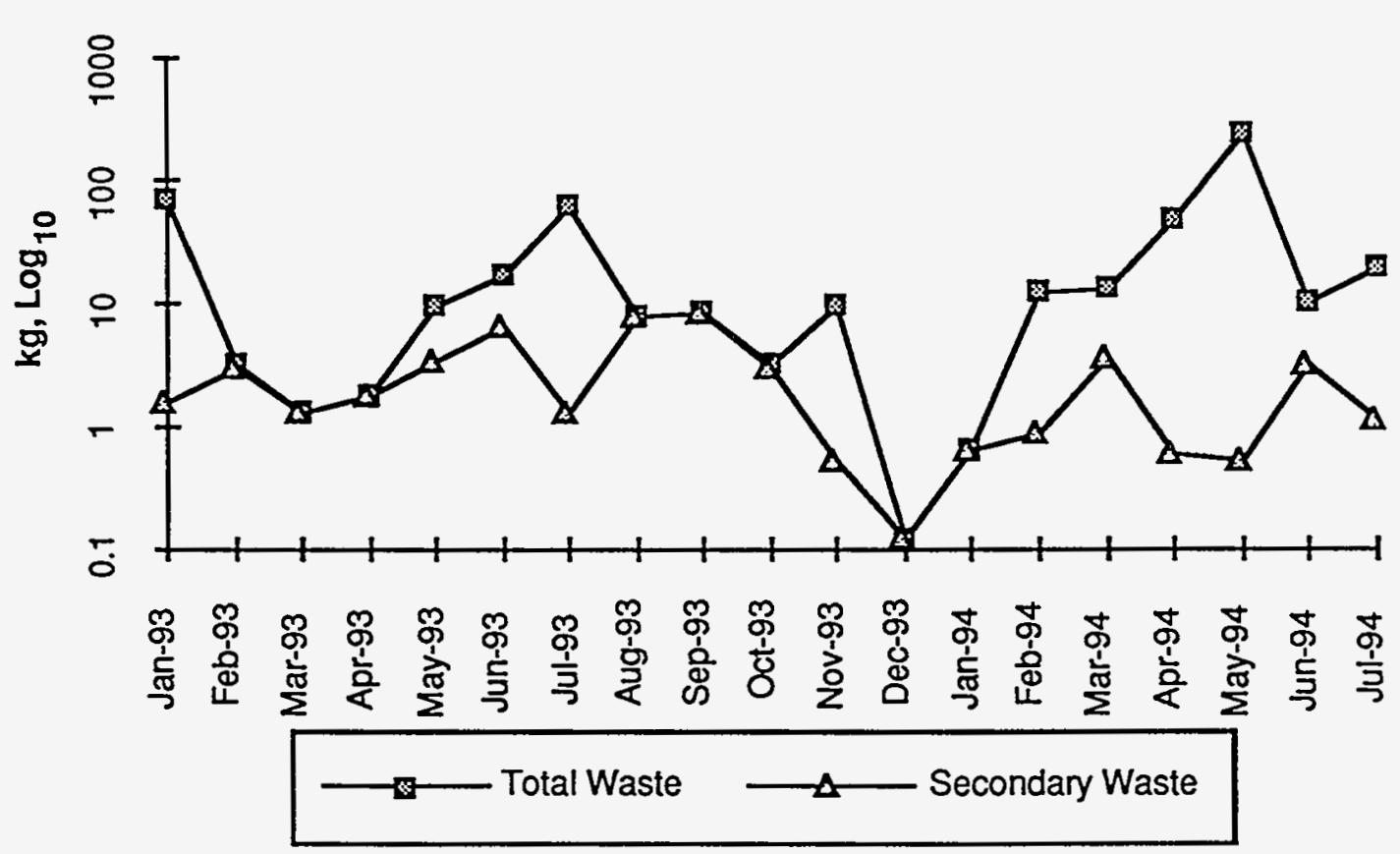

Figure 6. Waste comparison showing secondary and total waste generated during spill cleanup. 


\section{Option \#5 Share Unused Chemicals Among Laboratories}

Description: The continued use of a material until it is gone can greatly reduce the necessity of laboratories to order more of a particular item than they need.

Type: Recycling/Reduction/Best Management Practice

Feasibility: The implementation of this option would require a computer database (which is in place), which could be used to notify laboratory personnel of the excess inventory available. The drawbacks of this option are:

- The shelf-life of certain chemicals is short. Partially full containers are often disposed of because the shelf-life of the item has expired.

- The purity of the chemical cannot always be ensured.

Estimated Cost/Savings: This idea has worked on a large scale and has reduced the amount of initial waste generated by the laboratories. However, using the chemical exchange program for the small amount of secondary waste generated in the waste management facilities would not be cost effective; i.e., the cost of implementation would exceed the savings.

Anticipated Reduction in Quantity: The secondary waste stream would not be significantly affected.

\section{Option \#6 Attribute Spill Cleanup to Generator's Waste Stream}

Description: Spills are the leading type of secondary waste generated. Waste management technicians respond to calls for spill cleanup. They stock and provide the cleanup materials, which are attributed to the secondary waste stream. This option would attribute the amount of waste generated during cleanup (including waste cleanup materials) to the generator of the spill.

Type: Operations/Procedural Change

Feasibility: This option would give organizations an incentive to minimize spills because they would be directly responsible for the amount of hazardous waste generated.

Estimated Cost: The cost of disposing of spills and cleanup materials would not change. The amount of spill cleanup material disposed of by Dept. 8642 is about four drums per year, at $\$ 250 /$ drum $(\$ 1,000 /$ year $)$.

Estimated Savings: Dept. 8642 would still maintain the spill cleanup materials and perform the cleanup; however, fewer spills would be expected because the line organizations would have more incentive to prevent them. Savings probably would not be significant.

Anticipated Reduction in Quantity: Spill cleanup waste cannot be eliminated entirely from the secondary hazardous waste stream. However, if generators were administratively responsible for their own spills, the incentive to handle hazardous materials more carefully may reduce the number of spills. 


\section{Option \#7 Do Not Slop Liquid Chemicals}

Description: Careless handling of liquid hazardous waste poses the following risks:

- a safety hazard to the people handling the waste and to those around them;

- possible spills, which cost time and money for cleanup and waste disposal;

- an increased risk of contaminating personal protective equipment. If waste is handled appropriately, the coats and gloves can be disposed of as municipal waste, and the air masks can be wiped down and reused.

Workers need to be more aware of safe work habits and of taking care in handling hazardous waste.

Type: Education

Feasibility: The implementation of this option is simple. Unannounced audits could be performed periodically to observe work habits and make workers more aware of them.

Estimated Cost: Auditors' time.

Estimated Savings: The savings would be in the reduced amount of wipes and contaminated personal protective equipment.

Anticipated Reduction in Quantity: The reduction in contaminated personal protective equipment and wipes would be less than $1 \mathrm{~kg}$ per year.

\section{Option \#8 Use Alternatives to Aerosols}

Description: Most of the aerosol cans in the secondary waste stream are from spray paint and spray adhesive. The paint is used to cover labels that no longer apply, and the adhesive is used to apply labels to containers and drums.

Type: Substitution.

Feasibility: Instead of using aerosol paints and adhesives, waste management personnel could use other types of products, which can be applied with a small, disposable brush. Aerosol cans that are used by the laboratories should be phased out as well, but they are beyond the scope of this report. Care would also need to be taken not to spill the other types of paint or adhesives.

Estimated Cost: Negligible. As the aerosol cans are used up, the new types of paint and adhesives would replace them. A 16-ounce aerosol can of paint costs about $\$ 6.50$. A 32ounce can of paint costs $\$ 6.99$. The cost comparison is similar for the adhesives. The cost of a small disposable paint brush is about $\$ 0.50$.

Estimated Savings: The cost of disposing of aerosol cans used by Dept. 8642 .

Anticipated Reduction in Quantity: About $4 \mathrm{~kg}$ of aerosol cans are generated per year in the secondary waste stream. Unlike aerosol cans, paint and adhesive containers are compactible, thus reducing the volume for disposal. The reduction in the amount of secondary waste disposed of after the phasing out of aerosols would be about $4 \mathrm{~kg}$. Also, products applied with a brush would not be used up as quickly as products in aerosol cans. 


\section{Option \#9 Enclose Waste Facilities to Prevent Storm Water Runoff}

Description: The main area between the two waste management buildings is not enclosed. Here, drums and containers of waste are stored in bays (sheds with open fronts), the fronts of which are covered by heavy canvas curtains. Occasionally, rain falls into a bay. To verify that no storm water runoff from the storage area contains hazardous material, the facility is equipped with a collection pond, which is sampled periodically. Enclosing the area would protect personnel, drums, and drum labels not only from rain, but also from dirt and heat.

Type: Source Reduction/Safety

Feasibility: Purchase of materials, a building permit, construction, and modification to the storage facilities' permits are required.

Estimated Cost: Construction of a roof would cost approximately $\$ 50,000$, including lighting and ventilation. Permitting modifications would cost between $\$ 5,000$ and $\$ 10,000$.

Estimated Savings: Drums and drum labels would not become weathered and require replacement. The storage bays would not contain water during the rainy season. The sump would not require as much cleaning. The cost of sampling debris and water entering the area would be eliminated.

Anticipated Reduction in Quantity: The container log from January 1993 to July 1994 shows that rainwater from Bay 4 generated $68 \mathrm{~L}$ of secondary waste, which had to be handled, sampled, and analyzed. 5 This waste would be eliminated if the facilities were enclosed.

\section{Secondary Radioactive Waste Minimization Options (Process Index \#AL-SNL/CA-961, BIdg. 961)}

The following options are listed in order of importance, as ranked by the 1-5-10 Matrix and the feasibility scoring. Feasibility of each option's implementation is discussed. Each of the options is listed below in Table 7, along with its respective normalized score and rank.

Options \#3 and 4 do not directly impact the secondary waste stream. Rather, they impact "upstream operations." However, they could significantly reduce the total amount of mixed waste generated. Therefore, they are discussed briefly after the other options.

Table 7. Options to Reduce Secondary Radioactive Waste

\begin{tabular}{|c|l|c|}
\hline Rank & \multicolumn{1}{|c|}{ Option } & Total Points \\
\hline 1 & Open packages in a lay-down area instead of in RMMAs & 1401 \\
\hline 2 & Package tritium cocktails in plastic bags for disposal & 1058 \\
\hline 3 & Use 7-ml cocktail vials & 1006 \\
\hline 4 & Reduce the number of RMMAs & 967 \\
\hline 5 & Improve safety habits & 950 \\
\hline 6 & Install hand blow dryer to eliminate paper towel waste & 838 \\
\hline 7 & Do not use Bldg. 961 as a radioactive and mixed waste storage area & N/A \\
\hline
\end{tabular}




\section{Option \#1 Open Packages in a Lay-down Area Instead of in RMMAs}

Description: Radiological materials and waste are transferred to the waste management facilities packaged in various containers. If a package is opened in the RMMA, the package and radiological material are both handled as radioactive waste. If a temporary lay-down area were set up adjacent to the RMMA, and the package were opened in the lay-down area, the package would not be considered potentially contaminated and could be disposed of as municipal waste (if it is not contaminated).

Type: Operational Procedures/Training

Feasibility: Laboratory personnel and RWRs could be trained to perform this process in one training session. The Standard Operating Procedure could be modified to make the use of a lay-down area a requirement. ${ }^{6}$ This change would be convenient for the RWRs and would add surety that contamination would not spread to the environment.

Estimated Cost: The cost of implementing this option would be the expense of one training session-about $\$ 200$ in training time and preparation.

Estimated Savings: The cost of disposing of the packing material as radioactive waste would be saved. Less than $320 \mathrm{~kg}$ of such waste was generated from January 1993 to July 1994.7

Anticipated Reduction in Quantity: All of the waste from packaging materials could be eliminated from the secondary waste stream.

\section{Option \#2 Package Tritium Cocktails in Plastic Bags for Disposal}

Description: When tritium scintillation cocktails are picked up for disposal, they are packaged in sectioned cardboard containers. As the cocktails are dumped into an open disposal drum in the waste management facility, the vials occasionally break, which increases the quantity of airborne tritium. The drum is opened for deposition of vials until it is full. Each time a vial breaks in the drum, the risk of personnel exposure to airborne tritium increases. After the cocktails are used, they could be put in plastic bags, which could be set in trays or double-bagged for pickup; thus, the RWRs could pick up the waste already packaged for disposal and put it in the drums.

Type: Operational Procedures

Feasibility: Implementation would be easy because the necessary bags are used on site.

Estimated Cost: None (again, because the necessary bags are used on site).

Estimated Savings: The risk of inhaling the airborne tritium would be reduced, thereby reducing potential health risks (the cost of which cannot be measured). The activity of the drum's contents would no longer need to be sampled each time it is opened. The chance of a spill or release to the environment also would be minimized.

Anticipated Reduction in Quantity: Waste generation would increase (not significantly), but safety would dramatically improve. 


\section{Option \#5 Improve Safety Habits}

Description: The faster employees try to accomplish their work, the more likely they are to disregard safety guidelines. Safety habits, which need to be observed, include:

- making accurate wipe surveys of representative areas,

- closely observing the boundaries of workers' breathing zones,

- accurately measuring contamination levels in the air, and

- paying attention to work practices that could cross-contaminate items or the environment.

Type: Housekeeping

Feasibility: Unannounced audits of the work practices performed in Bldg. 961 could be done. These would provide incentive for RWRs to be more aware of safety habits.

Estimated Cost: Auditors' time and the amount of time workers take to pay closer attention to improving their safety habits (which would be minimal).

Estimated Savings: The cost of disposing of waste, such as cross-contaminated equipment and spill materials, would be saved. The cost of any occurrences caused by inattention to safety habits also would be saved.

Anticipated Reduction in Quantity: Of the waste generated between January 1993 and July 1994, $81 \mathrm{~kg}$ was concrete powder (a one-time waste stream) and $9 \mathrm{~kg}$ was spill cleanup materials, ${ }^{7}$ which could be reduced by more careful handling.

\section{Option \#6 Install a Hand Blow Dryer}

Description: The Standard Operating Procedure for Low-Level Radioactive and Mixed Waste Handling dictates that waste management technicians wash their hands after handling radioactive or mixed waste or materials. ${ }^{6}$ The paper towels they use to dry their hands are disposed of as radioactive waste. The use of a hand blow dryer would eliminate the use of paper towels.

Type: Recycle/Substitution

Feasibility: The placement of the air dryer is critical. The dryer must be placed in an area in the building where its use will reduce the chance of causing contaminants to become airborne.

Estimated Cost: The cost of the hand air dryer-approximately $\$ 350-$ and the cost of electricity to run the dryer would be the only costs incurred.

Estimated Savings: Dollar savings would be minimal, but this option would eliminate paper towels in the secondary waste stream.

Anticipated Reduction in Quantity: From January 1993 to July 1994, the amount of the potentially contaminated paper towels generated was about $10 \mathrm{~kg} .{ }^{7}$ If the air dryer were installed, none of this sanitary waste would be generated. 


\section{Option \#7 Do not use Bldg. 961 as a radioactive and mixed waste storage area}

Description: A) Bldg. 961 is a large building to maintain and survey for radioactivity. Hazardous waste also is handled in this building and could be cross-contaminated by radioactive or mixed waste. A different location could be chosen for transferring low-level radioactive waste, such as Bldg. $968, \mathrm{Rm}$. 129 , which already stores unclassified radioactive waste. No packaging is done in Bldg. $968, \mathrm{Rm}$. 129. This location is now large enough to handle all the radioactive waste generated on site because steam cleaning decontamination is no longer done, and the equipment has been disassembled and disposed of.

B) Mixed waste (specifically, tritiated oil) is stored in Bldg. 961. Currently, SNL/California has no means of disposing of this waste. The generation rate of tritiated oil is declining (now about one drum per year) because the TRL is being cleaned and transitioned to other uses. The tritiated oil generated here could be transferred to SNL/New Mexico for processing and disposal.

Type: Operational Procedures

Feasibility: A) This part of the option would be easy to implement. Transfers merely would be made to a different location. Classified waste would need to be separated from unclassified waste. However, the cleanup and transition of Bldg. 968 reduces the likelihood that this option would be implemented. B) Sandia corporate is assessing the option of managing SNL/California mixed waste at SNL/New Mexico and is comparing the costs of storing the mixed waste on site to the cost of transferring it to SNL/New Mexico for treatment and disposal. The standard operating procedure that controls activities in Bldg. 928, Rm. 129, would need to be changed. ${ }^{9}$

Estimated Cost: A) No cost. B) Cost of shipment to SNL/New Mexico.

Estimated Savings: A) The cost and liability of maintaining two low-level radioactive waste storage facilities would be reduced. B) The cost of storing and handling mixed waste would be reduced.

Anticipated Reduction in Quantity: None.

\section{Option \#3 Use 7-ml Cocktail Vials}

A smaller tritium scintillation cocktail vial would perform the same function as a larger vial and would reduce the amount of low-level radioactive waste generated.

\section{Option \#4 Reduce the number of RMMAs}

Reducing the number of RMMAs would greatly decrease the potential of cross-contamination and would increase the control of radioactivity. 


\section{References}

1. U.S. Department of Energy (DOE), Order 5400.1, General Environmental Protection Program (November 9, 1988).

2. U.S. DOE, Order 5400.3, Hazardous and Radioactive Mixed Waste Program (February 22, 1989).

3. U.S. DOE, SNL/California, Pollution Prevention Opportunity Assessment Plan for SNL/California, PD457712 Issue A (August 1994).

4. U.S. DOE, SNL/California, Safe Operating Procedure for the Hazardous Waste Storage Facility, SP472383 (current issue).

5. U.S. DOE, SNL/California, Hazardous Waste Container Log (1993, 1994).

6. U.S. DOE, SNL/California, Standard Operating Procedure for Low-Level Radioactive and Mixed Waste Handling, SP485007 (current issue).

7. U.S. DOE, SNL/California, Low-level Radioactive Waste Container Log $(1993,1994)$.

8. N. M. Phillips, SNL/California, Operating Procedure for the Recycling of Glass Hazardous Waste Containers, OP472425 (current issue).

9. U.S. DOE, SNL/California, Standard Operating Procedure for Low-Level Radioactive Waste Bldg. 968, Room 129, SP472690 (current issue). 
INITIAL DISTRIBUTION:

U.S. Department of Energy (3) Albuquerque Operations Office

Attn.: T. Pietrok, KAO

J. Orban, WMD

O. Critchfield, WMD

P. O. Box 5400

Albuquerque, NM 87115

MS1305, R. Davis, Org. 7576

MS1305, M. Walsh, Org. 7576

MS9001, J. C. Crawford, Org. 8000

Attn.: E. E. Ives, 5200

J. B. Wright, 5300

M. E. John, 8100

R. J. Detry, 8200

W. J. McLean, 8300

L. A. Hiles, 8400

P. N. Smith, 8500

L. A. West, 8600

R. C. Wayne, 8700

M. T. Dyer, 8800

D. L. Crawford, 8900

MS9021, K. W. Gordon, Org. 8535

MS9221, T. Gorman, Org. 8641

MS9221, D. A. Wright, Org. 8641

MS9222, S. Braye, Org. 8642

MS9222, R. Dagley, Org. 8642

MS9222, E. Dolstra, Org. 8642

MS9222, L. Farren, Org. 8642

MS9222, R. Garcia, Org. 8642

MS9222, G. Faulkner, Org. 8642

MS9222, D. N. Nissen, Org. 8642

MS9222, P. M. O'Brion, Org. 8642

MS9222, S. C. K. O'Connor, Org. 8642

MS9222, N. M. Phillips, Org. 8642 (15)

MS9222, S. J. Raubfogel, Org. 8642

MS9222, D. B. Ross, Org. 8642

MS9222, K. K. Shepodd, Org. 8642

MS9222, T. Larson, Org. 8644

MS9671, J. Bartel, Org. 8281
MS 9022, Mail Distribution Team, 8533-1, for OSTI (10)

MS9022, Mail Distribution Team, 8533-1/ Technical Library, 13414

MS0899, Technical Library, 13414 (4)

MS9018, Central Technical Files, Org. 8523-2 (3) 